DE DE GRUYTER OPEN
Research Article

(C) 2018 Chukwuma C.C. Osakwe and Bulus Nom Audu. This is an open access article licensed under the Creative Commons Attribution-NonCommercial-NoDerivs License (http://creativecommons.org/licenses/by-nc-nd/3.0/).

\title{
The Nigeria Led ECOMOG Military Intervention and Interest in the Sierra Leone Crisis: An Overview
}

\author{
Chukwuma C.C. Osakwe (PhD) \\ Associate Professor, Department of History and War Studies, Nigeria \\ Defence Academy Kaduna, Nigeria \\ Bulus Nom Audu \\ Lecturer, Department of History and International Studies, \\ Nigeria Police Academy, Wudil, Kano State, Nigeria
}

Doi: $10.2478 / \mathrm{mjss}-2018-0079$

\begin{abstract}
While Nigeria was under President Sani Abacha's dictatorship, the democratic system was toppled in Sierra Leone by rebels but Abacha reversed the trend. The reasons for the largely unilateral and hasty decision to restore democracy in Sierra Leone by the Abacha regime remain controversial. Wide skepticism and condemnation greeted the decision to commit Nigerian troops, money and materials to a foreign operation at the expense of Nigeria's fragile economy. The Nigeria Armed Forces consequently became the instrument for the pursuant of an aggressive foreign policy. The Economic Community of West Africa Monitoring Group (ECOMOG) hastily deployed to Sierra Leone just as it had previously done in Liberia amidst various operational and logistical problems. In terms of interests, Nigeria's attempt to restore democracy in Sierra Leone was perceived to be contradictory both at home and abroad since Abacha's regime itself was undemocratic and facing international isolation. The view that the Force was being used by the Abacha regime to pursue its own economic and political interest dampened the enthusiasm of regional and international organizations to provide financial and logistic support. Either way, the argument of this paper is that Nigeria's unilateral military action in Sierra Leone was a reflection of her desire to score a quick military victory outside an Economic Community of West African States (ECOWAS) sub regional security legal framework but it failed woefully.
\end{abstract}

Keywords: ECOWAS, ECOMOG, NIBATT, UNOMSIL, R.U.F., SLA, Peace-Enforcement, Peacekeeping

\section{Introduction}

The argument for and against Nigeria's Military operation in Sierra Leone has continued to feature prominently in West African military literature years after the end of the operation. While some justified Nigeria's Military intervention in Sierra Leone as part of her foreign policy obligations others have decried it for having ulterior motives. What was clear however especially at the domestic level is that, wide skepticism and condemnation greeted the decision to commit Nigerian troops, money and materials to a foreign operation at the expense of Nigeria's fragile economy. Thus, similar to the operation in Liberia, Sierra Leone cost Nigeria much more heavily than would have been the case if relations with the West had been harmonious.

Nigeria continued to bear over $70 \%$ of the financial cost for sustaining ECOMOG in Sierra Leone. A BBC news source had put the cost of Nigeria's involvement in Sierra Leone at almost 8 billion dollars (Sierra Leone profile, 2008). Nigeria had not only spent a lot on welfare, allowances, food, medical and other essential needs alongside the equipment, logistics and weapons of 
contributing countries, but was also paying the salaries and allowances of their troops (e.g. Niger Republic and Sierra Leone) (Kusa, 2007). However, all this becomes insignificant when one considers the painful fact that a large number of troops died because they lacked sufficient body armor, welfare, and logistics while fighting, while some were maimed and incapacitated for life without adequate compensation or any form of insurance for them and their families (Colonel $\mathrm{Y}$. Dambo, Nigerian Army, interviewed September 23, 2008, Abuja).

Just like the mission in Liberia, Nigeria's intervention in Sierra Leone was also a foreign relations matter. In this case however, Nigeria's initial actions were more unilateral. This was a reflection of the desire of Nigeria to score a quick victory without other ECOMOG components, but it failed woefully. The mandate of the Nigerian soldiers was very clear: to use war strategies to sack the junta of Major Johnny Koroma, restore order and reinstate President Tejjan Kabbah to power (Soja, 2000: 29). This position is in contradistinction of the indirect way Nigeria initially intervened in Liberia.

The operation was not authorized by ECOWAS though it was later given the authority of an ECOMOG operation when it was joined by smaller contingents from Ghana and Guinea. ECOWAS leaders were cautious over the use of a military solution and states such as Ghana that had participated prominently in ECOMOG in Liberia refused to embrace another full scale military operation in Sierra-Leone when the cost of the Liberian operation was still fresh in their minds. The operation was criticized by some members of the international community who argued, for example, that there was no agreement that authorized such a military operation in support of the disposed Sierra Leonean President. But Nigeria claimed to have intervened because of the bilateral defense agreement it signed with Sierra Leone in March 1997. As Sierra Leone sank deeper into crises even after the reinstatement of Kabbah to power, the U.N. Security Council had to establish the United Nations Observer Mission in Sierra Leone (UNOMSIL) in 1998 to complement the efforts of ECOMOG. Abacha's real motives for restoring democracy to Sierra-Leone when he was suppressing it at home are not too clear.

W.A. Fawole (2003:61) says, in the years when the military held sway, Nigeria's external relations went through a series of twists and turns, depending on both the character of the regime in power at any point in time and the personal idiosyncrasies of the different leaders thereby influencing the choices that the country made, and the strategies and methodologies adopted for accomplishing their set objectives. Coupled with Nigeria's 'big brother' or 'Power status' in Africa, these were factors that played a role in determining Nigeria's next line of action in addressing conflicts in the West African sub region. But Inno Ukoeja (1998:71-72) questions Nigeria's capability to police the whole of Africa. He states that the constitutions says that "the state shall promote African unity" and not that "the state shall police African unity". Thus, he wonders why Nigeria must carry the great burden of ensuring the policing of African unity, emancipation of the entire black race all over the world, etc, whereas all these tasks could be channeled through the Organization of African Unity so that other member States could contribute their own quotas in this noble aspiration. For security reasons, he also believes Nigeria should no longer enrich other African countries and solve their problems while the country's masses live in misery and poverty.

On the other hand, other scholars like Kuna (2006:5) support the argument that Africa should remain the centre-piece of Nigeria's foreign policy. The justification is that "given contributions in the maintenance of world peace through the UN, given its enormous human and natural resources, given its experience and capabilities in Regional conflict management as seen through the activities of ECOMOG in Liberia, Sierra Leone, Togo, guinea Bissau, and Equatorial Guinea and given the changing nature of global conflict, Nigeria stands in a good position to continue and always represent Africa and black people all over the world and make that the centre piece of her foreign policy." Kuna (2006:7) also adds that over the past twenty-five years, Nigeria has emerged from a relativity obscure position under colonial domination to a major participant in international peacekeeping. As he notes, by December 2000, Nigeria had 3,404 troops serving under the U.N., making her the second largest contributor to U.N. peace-keeping missions in the world after Bangladesh. Its leadership both as chair of the Security Council at various times, as well as in the U.N. system has given it the opportunity not only to build peace but also to push for positions favourable to Africa (Kuna, 2006). 
But A. Omede (2007:116) states that there are various problems that Nigeria must confront in order to enhance its effectiveness in future ECOMOG operations. She notes that the Nigerian Army for example encountered a lot of problems during the ECOMOG peace operations such as: lack of a credible mandate, inability to get the support of the majority members of ECOWAS particularly the Franco-phone countries, Nigeria's unilateral funding in the Liberian and Sierra Leone operations etc. However, Omede does not emphasize the fact that despite these challenges, Nigeria's military regime at the time (instead of first addressing some of the problems which were visible from the start) still saw it fit to saddle the nation's Armed Forces with the responsibility of spearheading a full scale military intervention in Liberia and Sierra Leone all under the guise of 'national security' considerations.

According to Braithwaite (1988:8-9), the term national security has long been used by politicians as a rhetorical phrase and by military leaders to describe a policy objective. Braithwaite further states that the origins of the concept of national security at least in the United States, can be found in the different historical formations of national interest, and can be traced back to the writings of James Madison and in its more recent manifestations in the writings of Charles Beard and Hans Morgenthau. In other nations of the world, national security is intrinsically linked to subjective formulations of their nation - state military socio/economic interest.

In developing countries including Nigeria, the strategic definition has tended to be the preference of the rulers. Consequently, national security in these countries is invariably perceived in terms of military build-ups to the neglect of other essential components of national security. He is referring to the internal political problems that characterize Third World nations which revolve round the legitimacy of the new regimes and the attendant internal struggles for political leadership (1988: 9). However, and ironically too, the failure to resolve their social, economic and political problems is the one singular factor that has led to their present security dilemma. Therefore, a narrow and militaristic perception of security is misleading.

Hence, the 1994 Human Development Report (HDR) of the United Nations Development Programme (UNDP) broadens the scope of security analysis and policy from territorial security to also the security of the people and thus adopts the term 'Human Security' over 'National Security' (Gomez, 2013). Hence, This paper adopts the holistic approach to security. Therefore the domestic, socio/economic and political environment of a sovereign state is the all important and critical factor in national security considerations. Put succinctly, national security is positively correlated with the increase in the distributive capability and genuine democratization of a given system. The tranquility and well-being of a society are pre-conditions for security. By well being, what is meant is the ability of the democratic state to provide its public with social economic and political conditions conducive to happiness and relative prosperity.

\section{Methodology}

Various works have examined the ECOMOG's role in the Sierra Leone civil war. However, not too many have reviewed Nigeria's perceived overbearing influence (as the leading contributing member and arrowhead) of not just the Force but the operation. Consequently, the aim and objective of this study is to analyze the implications for the Nigerian led ECOMOG Forces of the interests and foreign relations posture of the Abacha regime during this period.

This study largely depended on secondary sources. This involved the location and examination of relevant publications or other sources of information to the research topic. Use of the internet was involved as well as the use of various libraries to collect materials on ECOMOG operations in Sierra Leone as far as they are useful to the subject of the investigation. Journals, newspapers, and published works on Nigeria's foreign relations and the Armed Forces during the Abacha regime were used. In carrying out this research, efforts were made to obtain some primary sources in the form of unclassified official records. Efforts were also made to interview some serving and ex-military officers etc. Data generated in these were used as a check and to supplement the information obtained from secondary sources.

This study follows the thematic approach. Thematic approach has to do with organizing and presenting the findings on the basis of similarity of ideas as opposed to the chronological approach 
based on sequence of events. In the thematic procedure, the sequence of events is maintained under each theme. In this way focus is easy to maintain in the description and analysis of issues throughout the study. The findings of this research are presented using both descriptive and analytical methods.

\section{Retrospective: Nigeria and ECOMOG's Sub Regional Perspective}

Before the Sierra Leone crisis, Nigeria had intervened under similar circumstances In Liberia between 1990 and 1996. Though the Sierra Leone conflict started in 1991, it was to a large extent an extension of the Liberian crisis. Both countries are contiguous neighbours in the Mano River region. In other words, had there not been a Liberian conflict there would have been no conflict in the neighbouring state of Sierra Leone and certainly there would have been no need for a Nigerian led ECOMOG intervention in Sierra Leone. But there was a spill-over of the Liberian conflict into Sierra Leone. At the same time, the largely Nigerian led Forces found themselves bearing the burden of Nigeria's foreign policy in the West African sub region.

However, Nigeria's Interest via ECOMOG in Liberia by this time can be better understood within the overall context of the country's declared Afro-centric policy in general and sub-regional integration in particular. It must be borne in mind however, that national policies can be subject to the idiosyncrasies of leaders especially in developing countries such as Nigeria that have yet to develop effective institutions and mechanism for routine policy making. The influence and preferences of leaders often loom large in the choices that their countries make in foreign policies. The then Nigerian President, Ibrahim Babangida was not different from this profile as he enjoyed wide latitude almost never before enjoyed by any of his predecessors. Babangida had a history of close personal friendship with the Liberian dictator, Samuel Doe. It was not surprising therefore that the rebel leader Charles Taylor saw Nigeria's policy towards his country as an agenda to prop up the Doe regime. Public opinion in Nigeria was unfavourably disposed to Babangida's intentions especially seeing that he was hell bent on directly engaging the country's Armed Forces in ensuring that Doe's growing unpopular regime remained in power (The African Guardian, October 1, 1990:11). Added to this was that Nigeria's influential position in the West African sub-region and the potentials for dominance generated fears, suspicion and resentment by most, smaller and weaker neighbors. This was exacerbated by French propaganda against Nigeria (James, 1992:131-132).

However, although the 1981 ECOWAS protocol of Mutual Assistance provided the legal framework used by ECOMOG for its peacekeeping operation, by the time of the Liberian crises since December 1989 and the subsequent formation of ECOMOG in August 1990, the Protocol was yet to be implemented in full as most of its basic organs (e.g. the Defence Council) were yet to be put in place. Yet it was the same Protocol that had now surprisingly provided the legal framework for the deployment of ECOMOG (Elaigwu, 2000:35). The ECOWAS standing mediation committee had also failed to obtain the cross sectional consensus for the mission although the first of the ECOWAS Heads of State and Government meeting in Bamako in November 1990 accepted the ECOWAS peace plan, including the provisions for the deployment of a Monitoring Group. The lack of consensus principally among the Francophone West African States (i.e. Burkina Faso, Cote d'Ivoire, Togo, Senegal etc) created bitter divisions within the peace-keeping diplomatic and military machinery (James, 1992:131). Again when ECOWAS leaders met in Banjul and took the decision to send in peace keepers into Liberia, it was clear to them that Charles Taylor would not welcome such forces. At two rounds of the meeting comprising Ghana, Nigeria, Sierra Leone and Gambia, Taylor refused to attend (Jumaire and Elaigwu, 1996: 16-17). Nevertheless, ECOMOG intervened thus introducing a new element into conflict resolution techniques.

\section{The Start of the Sierra Leonean Crises}

The origin of the crises in Sierra-Leone can be traced to the struggle for political power between major political parties since independence. It is important to note that elections had been contested on ethnic lines, and politicians had exploited this growing phenomenon. This explained the controversy that greeted the All Peoples Congress (A.P.C.) victory and the circumstances that led 
the politicians to invite the military to take over power thus leading to a succession of military coups and counter coups, which ultimately resulted in the enthronement of the A.P.C. as the ruling party. The A.P.C. managed to maintain Sierra-Leone's political stability for almost twenty four years through an extensive and intensive policy of patronage and intimidation the government totally relied on. Hence, political parties were banned and politicians who stood in the way were either coopted into service through inducements or intimidation (Oni, 2013:113).

The ability of the A.P.C. to use the military as a means to foster its ends was systematic. It politicized the military through restructuring in such a way that recruitment was based largely on ethnic, regional and political affiliation thus leading to a decline in military professionalism (Oni, 2003). The Sierra-Leonean Army itself had become a corrupt institution whose primary role was the protection of those in power. The overall effect of the government's policy was a general decline of Sierra Leone's national institutions and also the national economy (Oni, 2003). Again, illegal diamond mining and smuggling led to the collapse of the real private sector as greed and embezzlement became common among the governing class. Questionable business deals enriched suspected investors and government officials even as difficult economic conditions saw Sierra Leone become one of the poorest countries in the world (Rake, 1989: 217).

These were the reasons that led to political activism, media attacks and general antigovernment activities (demonstrations) by students, intellectuals, and other pressure groups bitter over government's ethnic patronage, anti political activities and inability to pay workers salaries. Consequently, an active political organization was formed and was immediately exploited by foreign governments with vested interest. At the end what emerged was the formation of the Revolutionary United Front (R.U.F.) by some lecturers and students of Fourah Bay College in 1982 (Oni, 2003). Corporal Saybana Foday Sankoh emerged as the R.U.F. leader with the objective to overthrow the government which it described as corrupt and whose initial popularity started to wane owing to a deteriorating economy. In April 1996, a faction of the N.P.R.C. (which is believed had some understanding with the R.U.F. particularly in relation to its diamond trade) overthrew Captain Valentine Strasser in a palace coup. Its leader, Brigadier Manda Bio subsequently initiated talks with the R.U.F (Aboagye, 1999:231). However the elections that were organized to return the country back to civilian rule saw Dr. Ahmed Tejan Kabbah of one of the opposition parties winning majority of the votes (Aboagye, 1996:236).

It now seemed that the R.U.F. was opposed to the handing over of power to politicians. In response and in an attempt to undermine the electoral process, the rebels abandoned the cease fire and launched a series of offensives in which a large number of civilians were once again killed (Aboagye, 1996). Despite these setbacks, in March 1996 Tejan Kabbah was elected and sworn in as President by the votes of Sierra-Leoneans in areas unaffected by the conflict. Sankoh did not recognize the legitimacy of Kabbah's government, and he demanded fresh elections. He continued to give various conditions for peace to be established. He demanded the withdrawal of foreign mercenaries (most of those employed by the government were from South Africa, and Britain known as 'Gurkha') (Mocker, 1970:16) as a precondition for the rebel demobilization. As time went by, the cease-fire was violated by sporadic rebel attacks. Once again, Sankoh had derailed the peace process this time with his demand for the allocation of Cabinet posts as a further precondition for the cessation of hostilities.

Following growing resentment of the armed forces over the government's constitution of the Kamajors from the ethnic Mende as an auxiliary Civil Defence Force (C.D.F.), additional clashes occurred between regular forces and the Kamajors (Bassey, 2001: 260-261). A series of peace meetings continued to take place between Kabbah and Sankoh. On an occasion, Sankoh was allegedly lured by some Nigerian officials to visit the Nigerian President. But upon his arrival at the Murtala Mohammed International Airport Lagos, he was arrested and detained and placed under house arrest in Nigeria for alleged possession of arms (Bassey, 2001). Later in February, forces loyal to Sankoh kidnapped members of the anti-Sankoh movement, together with the Sierra Leone Ambassador to Guinea and used them as a bargaining chip for the release of Sankoh. Sankoh was never released by Nigeria, which tightened restrictions on the R.U.F. leader for making calls to the B.B.C. in the wake of the May 25, 1997 military coup which brought Major Johnny Paul Koromah to power (Elaigwu, 2000:35). 
Koromah successfully led an assault and succeeded in expelling Kabbah from the Presidential Palace. Kabbah was however lucky to escape to Lungi international Airport with the help of a detachment of Nigerian troops deployed at the Presidential Palace (Elaigwu, 2000).

\section{Nigeria's Policy towards Sierra-Leone}

Nigeria's leadership in forming ECOMOG to protect President Samuel Doe of Liberia was a vehicle for her to project its influence throughout the region. With a settlement in Liberia, Sierra Leone became the frontline of Nigeria's regional security role. Nigeria's military ruler, General Sani Abacha pursued the war since 1997 to ensure the survival of Sierra Leone's democratically elected government.

Thus, with the U.N. also having joined the global community in condemning Nigeria for her human rights abuses, and failure to restore democracy at home, Nigeria under Abacha apparently in a bid to seek legitimacy for his government (which in contradiction was undemocratic itself) concentrated her global participation efforts to ensuring peace in Sierra-Leone through its leadership role (Ashafa, 2000:11). And the junta also doubted Nigeria's neutrality considering the cordial relationship that existed between Nigeria and Kabbah's Government. At the Organization of African Unity (O.A.U.) Heads of government meeting that took place in Harare Zimbabwe (June 3, 1997) Nigeria's Foreign Minister at the time, Tom Ikimi as Human Rights Watch rightly gathered, denied that Nigeria's action was an interference in Sierra Leone. He said that:

This is not interference. We at ECOWAS have always been interested in explosive situations that take place in our region which we see as endangering civilian lives and disturbing peace. Together with the international community we must not allow such a situation to continue. Nigeria is going to ensure that peace, stability and legitimate government are restored in Sierra Leone.

Secondly and most importantly, the coup presented a tasking challenge to Nigeria which had in March 1997 concluded a bilateral defence agreement with Sierra-Leone. One Infantry Battalion and an artillery battery of the Nigerian Army were provided for security of the seat of government and relief of Sierra Leone armed forces engaged in enormous national defence duties in view of the rebel war (Soja, 200:29). The presidential guards were also provided by Nigeria as part of the assistance to the government. These were in addition to the Nigerian Army Training Assistant Group (NATAG) training activities (Soja, 2000: 5). 'When state security was threatened with series of coup plots and attempts which had become rampant in the country, Nigeria provided military intelligence and security experts to objectively assist the Sierra Leone government in investigations (1996-1997)'. (Soja, 2000)

\section{ECOWAS and the New ECOMOG Mandate}

Nigeria's intervention in Sierra Leone took the form of a request made by Tejjan Kabbah to the then Chairman of ECOWAS, Sani Abacha. The Chairman later contacted the members of ECOWAS (Elaigwu, 2000:35). ECOWAS leaders condemned the coup and ordered Kabbah's reinstatement. Sierra Leone's populace and various international organizations were also still yet to grapple with the reality of the R.U.F. in power. In fact, there had been student's and worker's strikes in mass with businesses closing down all in condemnation of the coup (Gberia, 2000). The same R.U.F. had been responsible for the high number of civilian deaths and displaced persons since the beginning of the conflict. Even more disturbing, thousands of defenseless civilians mostly women and children were amputated, and there was unprecedented looting. Children as young as nine years were forced to join the rebel group to perform combatant duties and to serve as shields while many women were abused and raped in a very barbaric and cruel manner (Aboagye, 1999:238).

ECOWAS recommended the establishment of an ECOWAS cease-fire monitoring Group in Sierra Leone to be known as ECOMOG II. On 29, August, 1997 the ECOWAS authority extended the scope of ECOMOG's activities to Sierra Leone 'to assist in creating the 'conducive atmosphere 
that would ensure the early reinstatement of the legitimate government of Sierra-Leone' (Time, October 20, 1997:21). Even though ECOWAS had now formally approved of the Nigerian-led ECOMOG intervention, ECOWAS member states were reluctant to endorse a full scale military operation which Nigeria preferred. Nigeria apparently lost faith in ECOWAS. Nigeria proceeded to implement these directives by military force (Blue Flame, January 2000: 37-38). Consequently, In January 1998, the Nigeria led ECOMOG II with support from the Kamajos led an assault on the military Junta. It was however not until February 15, 1998, that the Nigerian led troops were able to flush out the Junta (who wrecked the capital as they retreated) and restored Kabbah to power.

\section{The Forces and the Operations}

The Nigerian led ECOMOG Battalions which were deployed from Kossoh International Airport (while ECOMOG Headquarters was to remain at Lungi International Airport for strategic and tactical reasons) for the operation were: 2nd Mechanized Battalion, 5th Motorised Battalion, 93rd Mechanized Battalion, 231st Tank Battalion and P and Q Batteries (321 FAR). 231st light Tank Battalion was to secure Waterloo- Masiaka highway, while the Benguna Training Camp was to be secured by 93rd Mechanized Battalion with the aim of preventing rebel access to the Peninsula road and clear the whole Kossoh area and environs (Gberie, 2000). With support from the Nigerian Air force and Navy ECOMOG Battalions launched concentrated artillery and mortar bombardments as part of 'Operation Sandstorm' on all earmarked targets. All these objectives were achieved by 6 February 1998 and proved successful in trapping the rebels within Freetown denying them access to outside the city in spite of the rebels resort to guerilla type offensives along the corridors (Oni, 2002:152). Many towns leading in and around Freetown were eventually cleared and secured, for example, Bo, Kanema, parts of Kono District, Masiaka, etc (Dambo, interview cited).

Generally the main aim of subsequent phased operations and deployments of additional Nigerian Battalions (NIBATTS) and loyal remnants of the Sierra Leone Army (SLA) in taking over other towns and routes was to seal the Sierra-Leone-Liberia border to deny rebels any support or reinforcement from Liberia as had been the case.

\section{The 1999 R.U.F. Invasion}

The fact is that though the R.U.F. was ousted with the Junta in February 1998, it was not totally crushed and had the capacity to operate effectively, even without Foday Sankoh. Its operational capacity had been founded on the mineral-rich areas it had been controlling in the North-Eastern provinces and the arms and ammunition cached during the junta rule (Oni, 2002:163). Apparently, with the benefit of smuggling networks established since mid-1997 and the ease with which it traded diamonds and gold for weapons and fuel, it was an illusion to think that the R.U.F. days were over.

Thus, in January 1999, the R.U.F. used the recent happening in Freetown to launch a 'blitzkrieg' type surprise offensive. January 1999 was the worst period and which saw the highest death toll for Nigeria. The rebel offensive was to prove to be the largest and most effectively coordinated rebel offensive launched in the history of Sierra-Leone and was under the command of Sam Bocharie the R.U.F. Commander (Oni, 2002). It seized the hills dominating Freetown and debauched into the densely-populated eastern Freetown in typical guerilla fashion after it recovered concealed weapons (it had prior hidden) from cemeteries and elsewhere within 10 days embarrassed ECOMOG as it pushed into western Freetown and seized the centre of the city, including Government House and the port of Freetown. According to media reports, rebels launched the offensive and were joined by rebels who pretended to be refugees at checkpoints (Just, 1999:32). ECOMOG forces gave them passage, it was a costly error. Prisoners at William Wilberforce prison were set free while the Nigerian Embassy was torched. Confusion set in (Just, 1999). The Government warned residents to stay indoors to avoid being shot by ECOMOG forces. But at the threat of death, the rebels forced them into the streets using them as shields in the battle for Freetown. Aided by Fifth Columnist, the rebels took the offensive to ECOMOG bases and cut down the soldiers there. Soldiers that were seriously wounded died slowly since the rebels set 
ablaze the main Connaught Hospital in the city (Just, 1999).

In fact, the entire northern Sierra-Leone was now in rebel hands and almost all of the Nigeria military units in these areas complained of the lack of adequate logistics, and fatigue due to insufficient manpower and poor troop rotation (Dambo, interview cited). Sierra-Leone was all the more spectacular because during President Kabbah's visit to military formations in September 1998, Major General Timothy Shelpidi, the ECOMOG Force Commander, had said that ECOMOG long before the offensive had liberated over $80 \%$ of Sierra Leone. Even the U.N. Observers present, as part of the U.N. Observer Mission in Sierra Leone (UNOMSIL), approved by the U.N. Security Council and established earlier in the country in January 1998 were forced to seek refuge at ECOMOG Headquarters (Just, 1999).

However the tide of the rebel offensive near the airport was turned when the U.N. Assembly vehemently and unanimously condemned the R.U.F. and some more support for ECOMOG started coming in from Nigeria, Ghana and Guinea. By now, ECOMOG had about 13,000 troops (in five brigade formations and the Freetown garrison) committed to Sierra Leone with Nigeria making up $80 \%$ of the troops (Just, 1999). The British Government also deployed its royal naval vessel H.M.S. Norfolk and H.M.S. West Minister to help ECOMOG swiftly move its troops and logistics (Just, 1999). ECOMOG reinforcements engaged the rebels in street to street and house to house combat. A Nigerian battalion led an advance on 10 January 1999 with heavy support from the fierce Kamajor's (C.D.S.) who understood the terrain much better. Despite stiff opposition by the rebels, the NIBATTS was able to aggressively fight its way through into Freetown, eventually capturing the state house and environs the following day (Lance-Corporal U. Idris, Nigerian Army, interviewed September 10, 2008, Kaduna). Despite these successes, the R.U.F.-A.F.R.C. alliance continued to dominate several parts of the country and retained considerable freedom of movement, and action to interdict ECOMOG lines of communication and conduct raids (Idris, interview cited). This continued up to the time of the establishment of the United Nations Mission in Sierra Leone (UNAMSIL).

President Olusegun Obasanjo took over from General Abdusalami Abubakar as Nigeria's democratically elected civilian president on May 29, 1999. The return of democracy to Nigeria in 1999 improved the country's image abroad and gave the country a full breathing space to take a more active and productive role regionally and on the global stage. President Obasanjo and Nigerians in general became much more vocal about their bitterness towards Nigeria's continued presence in Sierra Leone especially seeing that Nigerian troops were dying in large numbers and billions of dollars were being spent (when Nigeria had little for itself) with no sign of total peace in sight. Consequently, the decision to gradually pull out Nigerian troops was a far reaching shift in the foreign policy of Nigeria. Despite Obasanjos diplomatic peace moves, Sankoh and the RUF in general continued to break agreements and even attack UN peacekeepers.

The war in Sierra-Leone effectively ended in January, 2002, after several failed attempts by the rebels to retake Freetown and the death of Foday Sankoh shortly after (Aboagye, 1999). Presidential and Parliamentary elections were conducted and Kabbah was re-elected (Sergeant Bassey, Nigerian Army, interviewed October 3, 2008, Kaduna). It can be said that in Sierra Leone, Nigerian troops discharged their duties credibly despite operational constraints. The United Nations Security Council had adjudged the mission a success. When the U.S. Secretary of State, Mandeline Albright visited Sierra Leone towards the end of 1999, she commended ECOMOG forces by rightly saying that they had paid a heavy price to end the fighting, adding that the world owed them thanks (Defense Newsletter, October-December 1999:21). Today Sierra Leone is relatively peaceful, though some of the conditions that led to the crises are still there.

\section{Conclusion}

Sierra Leone's relative peace came at a bitter price for the Nigerian Armed Forces and the country's fragile economy. Nigeria was virtually the only country in Sierra Leone since ECOWAS member States did not appear too enthusiastic about committing troops to keep the peace after the restoration of Kabbah back to power. Despite its misgivings about the Abacha regime, the U.N. response and that of the international community in general had been more positive than it had been in Liberia, but like Liberia, the response came late, and came amidst fears of Nigeria's 
decision to pull out its troops. Abacha's real motives for restoring democracy to Sierra Leone when he was suppressing it at home are not too clear. However, in this case, Nigeria's initial actions were more unilateral than it had been in Liberia. This was a reflection of the desire of Nigeria to score a quick victory without other ECOMOG components, but it failed woefully. In other words, the Nigerian Armed Forces were the ones that had to bear the brunt of the regime's relations abroad.

\section{References}

Aboagye Festus (1999). ECOMOG, a Sub-Regional Experience in Conflict Resolution Management and Peacekeeping in Liberia, Accra: Sedco Ltd.

Ashafa A.M. (2000). Nigerian-Led ECOMOG Intervention in the Sierra Leonean Crises, Issues and Problems, Defence Studies, Vol. 10, July, pp. 1-25

Bassey Ufot (2001). Foreign Policy Decision Making in Nigeria, London: London University Press.

Braithwaite Tunji (1988). Foundations and Dynamics of Security, Nigerian Journal of International Studies, Vol. 12, pp. 8-16.

Defence Newsletter (Vol. 1, N0. 1, October-December, 1999), pp. 21-29.

Elaigwu Victor (2000). ECOMOG and the UNO: The Challenges of International Peacekeeping, Defence Studies, Vol. 10, July, pp. 26-41.

Fage Kamilu (1999). Nigeria's Defence Policy and the Challenges of the Twenty-First Century, Defence Studies, Vol. 9, July, pp. 1-16.

Fawole Alade (2003). Nigeria's External Relations and Foreign Policy under Military Rule (1966-1999), lle-Ife: Obafemi Awolowo University Press Ltd.

Gberie Lansana (2000). A Dirty War in Africa: The RUF and the Destruction of Sierra Leone, London: Hurst and Co. Ltd.

Gomez Oscar (2013). A Thematic Guidance Note for Regional and National Human Development Report Teams, prepared for the Human Development Report Office, United Nations Development Programme.

Jumare M. and Elaigwu V. (1996). The Evolution of International Peacekeeping and the ECOMOG Operation, Defence Studies, special issue on ECOMOG, pp. 11-25.

Just (February 1999), p. 32.

Mocker Anthony (1970). Mercenaries, London: Macdonald and Co. Ltd

Newswatch, (April 15, 1991), p.30.

Nwolise Osisioma (2004), The Nigerian Military in Peacekeeping since Independence, in W. T. Gbor (ed.), Military History, Nigeria from Pre- Colonial Era to the Present (pp. 103-114). Lagos: Longman Nigeria.

Omede A. (2007). Challenges Confronting the Nigerian Armed Forces in Peace Support Operations, in Alexander Ogomudia (ed.), Peace Support Operations, Command and Professionalism: Challenges for the Nigerian Armed Forces in the $21^{\text {st }}$ Century and Beyond (pp. 115-136). Ibadan: Gold Press Ltd.

Oni S. K. (ed.) 2002. The Nigerian Army ECOMOG Operations: Liberia and Sierra Leone, Ibadan: Sam Bookman.

Rake Alan (ed.) (1979). New African Yearbook, London: I.C. Media.

Sierra Leone profile (2008). [Online] Available: http://news.bbc.co.uk/2/hi/africa/countryprofile/2364039.htm

Soja, (Vol. 22, April-June 2000).pp. 1-38.

The Diet (August 12, 1997), p.1.

Time (October 20, 1997), p. 21

The Blue Flame (January 2000), pp. 37-38.

Ukoeja Inno (1998). Nigeria's Security and the Great Power Politics, Nigerian Journal of International Studies, Vol. 12, pp. 70-77. 